$\xi=-1$

\title{
Balanced Scorecard as a Performance Measurement System in Malaysian Private Institutions of Higher Learning: Empirical Findings
}

\author{
Mohamad Hafiz bin Rosli ${ }^{1}$, Farrah Fawzia binti Md Ariff ${ }^{2 *}$ and Jamaliah binti Said ${ }^{3}$ \\ ${ }^{1}$ Faculty of Business and Accountancy, Universiti Selangor, Selangor, Malaysia \\ ${ }^{2}$ Faculty of Business and Accounting, Infrastructure University Kuala Lumpur, Selangor, Malaysia \\ ${ }^{3}$ Accounting Research Institute and Universiti Teknologi Mara, Selangor, Malaysia \\ *Corresponding author E-mail: farrariff@yahoo.com
}

\begin{abstract}
Balanced Scorecard (BSC) is a well-known performance measurement tools and some researchers have highlighted its relevance to Institutions of Higher Learning (IHL). In order to response to the globalization phenomenon today, IHL must adopt the most suitable tool such as Performance Measurement System (PMS) in assessing academicians' performance. The adoption of Strategic Performance Measurement System (SPMS), proven to realize significant cost saving, improve personal satisfactions and enhance organizational performances based on previous studies. Therefore, the objective of this paper is to determine the relationship between leadership, communication and academic qualification towards the adoption of BSC. Data were collected quantitatively through a survey questionnaire with the usable response rate of $78.57 \%$. The descriptive results of this study revealed that the majority of academicians' extensively agrees that the measurement used in the BSC are effective in assessing academicians' performances. This finding also reveals that leadership, communication and academic qualification were significantly influenced the adoption of BSC. The findings from this study have advanced the literature on BSC especially in the education sector. It also provides a better understanding of BSC as the performance measurement tool in assessing academicians' performance.
\end{abstract}

Keywords: Balanced Scorecard, Private Institution of Higher Learning, Performance Measurement System, Strategic Performance Measurement System.

\section{Introduction}

Private institutions of higher learning (IHLs) are as important as the public ones to turn Malaysia into a regional higher education hub by 2020. Arokiasamy [1] indicated that the roles of private IHL are similar to the public IHL including teaching, research and publications and administration, and in fact they have to be innovative in their programs, fee requirements and the ever-changing needs of students to generate their own revenues without compromising its quality. Private IHLs' are facing challenges to maintain the educational quality and the demand is increasing. To cater to the demand for educational quality, performance measurement system (PMS) and strategic mechanism through planning, monitoring and controlling in an educational environment to ensure it is successful is needed [1]. Hence, with the performance measurement indicators, they able to further improve their weaknesses and ensure university competitiveness [2].

Balanced Scorecard (BSC) is one of the most prominent Performance Measurement System (PMS) in organizations because it stresses four important aspects of the organization's strategies into a single and balanced framework [1]. Among all methods, BSC is chosen widely as an extensive and a comprehensive performance evaluation tool to adequately plan and control an organization aligning with their vision and goal [3]. Kaplan [4] indicated that the financial measure of a company's performance be supplemented with other measures that will capture the intangible assets of the growth, were to complement financial ones to give a clear picture of the company's performance. Prior literature revealed that there were limited studies that examined the adoption of BSC as a tool in measuring the performance in higher learning institutions (IHL) especially the perception among academicians. To our knowledge, no prior studies have examined the adoption of BSC in the education sector at individual level. Only studies that examined at unit, department and organization as a whole, but none at individual level. Therefore, this study aims to examine the extent of BSC adoption and investigate the factors that associated to the BSC adoption.

\section{Literature review}

\subsection{The Concept of Balanced scorecard}

BSC was first developed by [4] as strategic performance measurement model to translate an organization's mission and vision into actual action (operational and strategic planning). BSC intends to combine the use of financial and non-financial measures such as customer, internal business process, and learning and growth so that managers are provided with more detailed information than financial measures alone [5]. Zain [6] mentioned that BSC specific indicators, namely financial, customer, internal business process, and lastly, learning and growth performance work as a balance measure of four perspectives.

Figure 1 presents the BSC structure developed by Kaplan and Norton which consists of four distinct measurement perspectives [5]. Gumport [7] revealed that, the combination both financial and non- 
financial perspectives within the four elements create a "balanced" approach to overcome the limitations of traditional PMS which relies on financial perspective only. BSC mechanism is considered as an assessment and measurement tool that enables the higher management of an organization to monitor the improvements in all area of the organization [7]. It is also acts as a management system to capture breakthrough competitive performance and is most successful when used to drive the process of change and recognition of that performance measurement should start from the organization's strategy $[8,9]$. Over the years, the BSC concept has evolved through a series of papers and books published by Kaplan and Norton transforming the scorecard concept from an innovative, but relatively simple performance measurement tool, to a complex PMS [5].

The integration of the four perspectives as shown in figure 1 creates a "balanced" approach to overcome the limitations of traditional PMS which relies on financial outcomes [10]. The financial perspective is important for shareholders and stakeholders, especially in regards to the key strategic business implementation and assessment of organizations' performance. To make the key strategy effective and reliable performance measures, Munir [11] suggested that the financial aspect has to be embedded into the organizations vision and mission statement and the transformation of financial issues into sustainable goals and minimal cost. Good financial strategic objectives and financial performance measures allow the organization to enhance long-term stakeholder values and expanding the market. Meanwhile, it can provide evidence of whether or not the company's financial strategy is increased in profit and decreased in costs [12]. Customer forms another important perspective to strengthen the financial strategy. Kaplan \& Norton [5] indicated that an organization needs to identify the two types of customers which the core measure group usually include customer satisfaction, acquisition, profitability and retention including market share. The second strategy is how organization position the customer value that includes product quality and attributes, image and relationship. Kaplan \& Norton [5] and Ittner, Lin, Yu, and Zhang, [13] suggested to organizations to include customer satisfaction indicators in internal PMS and compensation plans.

From the perspective of internal processes, organizations should continue to conduct dynamic innovation in products, services and more customer value [14]. The internal process can be referred as a business strategy to supply chain which develops services for customers. Learning and growth are two important features that every organization's strategy should incorporate with. Human, information, and organization capital, culture, alignment, and teamwork are the important indicators and intangible assets that can be used to depict these features as indicated by [12]. Kaplan \& Norton [5] argued that organizations' capital, employees, and knowledge systems are important for this perspective. Meanwhile, organization's employees, infrastructures, and environment, and reflects employee satisfaction, motivation, empowerment, and the capabilities of employees and information systems are urged to facilitate the performance of the other three perspectives [14,15]. Kaplan \& Norton [5] proved that learning and growth perspective are related to the organization's internal skills and capabilities.

\subsection{Application of $\mathrm{BSC}$ in education}

Chen et al. [15] the introduction of the BSC in an educational institution requires faculty staff to work together and it begins with the top leader who carries the responsibility for policy making and execution in a top-to-bottom hierarchy. Furthermore, implementing the PMS such as BSC would enable IHL to allocate resources in a well-planned manner thus, making this implementation rendered into an effective reorganization of daily operations such as staff daily tasks. Previous studies reported that almost more than $80 \%$ of the top 1000 corporations used BSC and the number keep increasing [16]. This supported by [17], BSC continues to be the most fit management tools for measuring performance in meeting the needs of stakeholders in various sectors and is still being applied until today.

Previous research has indicated and addressed the suitability of BSC in commercial industry such as in public, manufacturing, hospitality, health care, e-services and supply chain business [18]. In nature, IHL is a non-profit organization, but they may be driven by business objectives. Their vision and mission normally focuses more on student's satisfaction rather than profitability concerns. AlTurki and Duffuaa [19] proposed a modified BSC in Hasanuddin University that is able to resolve problems encountered in managing the institution. This study proved that IHL needs to visualize precisely the strategy map according to its own characteristics and strategy. Besides strategy, Nejati, Farid, and Mirfakhredini [20] indicated that IHLs are suggested to apply other non-financial perspectives such as community participation, innovation, strategic partnership and scientific research excellence in order to assess the performance of higher education institutions.

IHL are one of the institution that also needs to apply PMS due to globalization competition. In the education sector, each school or faculty will need to establish their core competencies, subject to their vision and mission and they also need to consider their current available resources and state of competitiveness. Most of the existing studies refer to the application of the BSC in higher education institutions, either through case studies, or through custom methodologies [13]

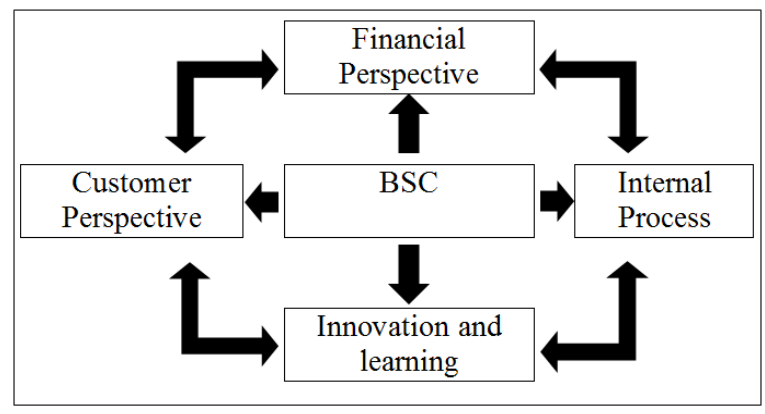

Fig. 1: The Structure of Kaplan and Norton's Balanced Scorecard (Schobel, 2012)

\subsection{Application of BSC in education}

Chen et al. [15] the introduction of the BSC in an educational institution requires faculty staff to work together and it begins with the top leader who carries the responsibility for policy making and execution in a top-to-bottom hierarchy. Furthermore, implementing the PMS such as BSC would enable IHL to allocate resources in a well-planned manner thus, making this implementation rendered into an effective reorganization of daily operations such as staff daily tasks. Previous studies reported that almost more than $80 \%$ of the top 1000 corporations used BSC and the number keep increasing [16]. This supported by [17], BSC continues to be the most fit management tools for measuring performance in meeting the needs of stakeholders in various sectors and is still being applied until today.

Previous research has indicated and addressed the suitability of BSC in commercial industry such as in public, manufacturing, hospitality, health care, e-services and supply chain business [18]. In nature, IHL is a non-profit organization, but they may be driven by business objectives. Their vision and mission normally focuses more on student's satisfaction rather than profitability concerns. AlTurki and Duffuaa [19] proposed a modified BSC in Hasanuddin University that is able to resolve problems encountered in managing the institution. This study proved that IHL needs to visualize precisely the strategy map according to its own characteristics and strategy. Besides strategy, Nejati, Farid, and Mirfakhredini [20] indicated that IHLs are suggested to apply other non-financial perspectives such as community participation, innovation, strategic 
partnership and scientific research excellence in order to assess the performance of higher education institutions.

IHL are one of the institution that also needs to apply PMS due to globalization competition. In the education sector, each school or faculty will need to establish their core competencies, subject to their vision and mission and they also need to consider their current available resources and state of competitiveness. Most of the existing studies refer to the application of the BSC in higher education institutions, either through case studies, or through custom methodologies [13].

\subsection{Performance Measurement System}

PMS has become the focus of discussion in recent years in response to the necessity for reforming IHL education system in line with the current needs and growing expectations from the community and business sector [21]. The awareness of the needs for PMS implementation has begun around the 1860s and 1870s, where it was based on a simple objective to monitor and maintain the organisational process [22]. Hassan, Amir, and Maelah, [23] in his working paper, "Conceptual Foundations of the Balanced Scorecard" he mentioned that his interest in the measurement in getting performance improvements arose from a belief articulated more than a century earlier by a prominent British scientist, Lord Kelvin.

I often say that when you can measure what you are speaking about, and express it in numbers, you know something about it; but when you cannot measure it, when you cannot express it in numbers, your knowledge is of a meagre and unsatisfactory kind. If you cannot measure it, you cannot improve it. (Kaplan, 2010, p.3).

The outcome that is obtained from the measurement processes given to the upper management evaluation should be parallel according to the desired business objectives and results in the future [7,24]. Globalization has made IHL to sustain and to achieve this sustainability IHL needs recognize a set of PMS as it will create a proper educational objective. A comprehensive and systematic sets of PMS in areas of the IHL's administration will leads to competitive advantage of IHL and such process ensures the quality of university operation, and also improves any weaknesses found [19]. Franceschini \& Turina [24], the initial main idea of IHL was to be a social institution, but the idea has transformed where IHL is currently perceived to be as a specific sector in which their goal is to cater to some of the workforce, economic development and perform research.

This transformation began 25 years ago in the United States [14] and it is now becoming a global trend where it emphasizes the way how universities are managed. As an example, [21,22] recognised the implementation of PMS through the Baldrige Education Criteria for Performance Excellence that has adapted the concept of BSC in the education sector.

\subsection{Strategic Performance System}

The Strategic Performance System (SPS) is a new found dimension of PMS system where the function is to enhance the interactivity among the management and the employees that can lead to higher performance. Non-financial perspectives such as motivation, customer service, satisfaction, time, quality, innovation, are proven as the strengths of SPS in assessing an organization's achievement [4]. According to Chenhall [2], the strength of SPS non-financial features, is to provide a way of translating strategy into a systematic set of performance measures. The non-financial measures have the following characteristics: an integration of financial and non-financial indicators; the presence of a forward-looking perspective; a combination of long-term and short-term horizons; internal and external viewpoints; the definition of causal relationships among the different measures and perspectives included in the system. This supported by Micheli \& Manzoni [25], they claimed that SPS will determine the successful of company's long-range plans. They reported that previous studies as indicated in table 1 have found SPS is generally productive and helpful in improving organizational performance and can benefit to the following areas [26]:

- Formulation, implementation and review of organisational strategy

- Communication of results achieved to stakeholders, thus strengthening the corporate brand and reputation

- Motivation of employees at all levels, promotion of a performance improvement culture, and fostering of organisational learning

Table 1: Example of SPS Application in Various Industries

\begin{tabular}{|c|c|}
\hline Authors & SPS Application \\
\hline $\begin{array}{l}\text { (Bigliardi \& Bottani, 2010) } \\
\text { (Yilmaz \& Bititci, 2006) } \\
\text { (Gimbert et al., 2010) }\end{array}$ & Food \\
\hline $\begin{array}{l}\text { Curtright, Stolp-Smith, \& Edell (2000), } \\
\text { Lin, Yu, \& Zhang (2014) } \\
\text { (Greiling, 2010) }\end{array}$ & Healthcare \\
\hline $\begin{array}{l}\text { Ittner et al. (2003) } \\
\text { (Hung, 2012) } \\
\text { Rotchanakitumnuai, 2013) }\end{array}$ & Financial Service \\
\hline
\end{tabular}

\subsection{Leadership}

Chenhall et. all., [2], mentioned that in their study, PMS effect the everyday individuals' behavior. Rogers [27], reported that communication skills, long-term strategic thinking, integrity and ambition are needed to achieve higher leadership quality. In other words, the leadership processes may have embedded motivating, committing, and leading together and thus leadership style will affect the implementation of the PMS [28] but according to [29] there has been limited research that has specifically addressed the relationship between leadership behaviour and organisational performance. A leader in an organization takes responsibility in their daily duty to lead any organizational change initiatives in order to achieve organizational objectives [13]. An organization needs an accountable leader to generate good outcome.

Moreover, to enhance leadership accountability at all levels and as one of the management accounting tools for balanced control, BSC can become not only as a measurement system, but also as a strategic performance management tool to achieve competitive advantage and sustain performance excellence $[11,15]$. As a successful performance management system, BSC also provides a basis for leaders to manage change or execute strategy better $[13,14]$ Nevertheless, a study on leadership styles and behaviors help the improvement of organizational performance [30]. The full application of an effective leadership framework may promote leadership accountability for sustainable performance excellence in the public sector.

Ukko, Tenhunen \& Rantanen, [31] highlighted that it is significant to study the performance measurement from the dimension of a leadership. There are various management accounting mechanism such as BSC, Activity Based Costing (ABC), Target Costing, and Budgeting [30] that needs support from the leaders as an important contingency approach. This supported strongly by Munir [11], his studies showed that leadership support is very important in PMS design and implementation, and a major contributor to the effectiveness of PMS is the willingness of a leader's time to reflect on measures. Further to that, a study by [13] showed that PMS that focuses on the employees' attention on issues that are important to the company linking key objectives to the employee's jobs and continuous review. Therefore, from all the previous study it is possible to find a clear connection between leadership style and performance measurement system. Hence, it is hypothesized that H1: there is a significant relationship between leadership and BSC adoption in assessing academicians' performance. 


\subsection{Communication}

Nowadays, communication is one of the most powerful activities in organizations'. Rajhans [32] indicated that the communication channel is the transmission of a message from a sender to a receiver, provided that the recipient of the sender's intended meaning of the message is created with the same meaning. He further explained that communication process can be linked to perform management functions such as planning, organizing, and controlling. This is supported by [33], they claimed that communication flow is one of the major interest of all organizations to increase the performance of their employees. Formation process and future survival of the organization crucially needs human communication for organizational operation.

Communication channel initiates individuals and groups to coordinate activities to achieve goals, and it is vital in socialization, decision-making, problem-solving and change-management processes [27]. Specifically, it reveals that management communication affects performance mainly because it signals that the organization cares about the well-being and values the contributions of its employees [24]. The culture of communication is helping the organization in a crucial way by enhancing employee understanding, building trust, stimulating engagement and better performance in the changing scenario [27]. Motivated employees are the most valuable asset of any organization where their performance has an impact on the whole organization. To improve organizational performance, we have to consider more deeply on how to improve the employees' performance [34].

If the employees feel that the management is communicating in an efficient manner, it motivates them to perform better and develop a team spirit which is vital for the smooth functioning of the organization where it promotes positive revenue growth [5,35]. Hence, to manage the existing performance of the employees and to motivate them to achieve better performance, efficient communication practices have become much more important in all organizations. Thus, it is hypothesized that $\mathbf{H 2}$ : there is a significant relationship between communication and BSC adoption in assessing academicians' performance.

\subsection{Academic Qualification}

Narang and Dwivedi, [36], indicated in their studies that the biggest achievement in the education industry based on several factors such as opportunities, qualification of academician, review of curriculum and development, communications of the institution with certified organizations and allocation of resources. Since quality assurance and compliance becomes an important issue in education area, IHL needs to ensure the performance of the academician to be measured and monitored because IHL achievement comes from the quality provided mainly by academicians [5]. In addition, high quality academician can help to mitigate any uncertainty and stimulate the process creation through emphasizing organizational and individual learning, so that the school can maintain efficient activities [12]. A study done in Pakistan, found out that IHL in that country unsuccessfully meeting the international standard as one of the top 300 ranking universities in the world. This is due to insufficient of dedicated and qualified academicians where they need $7000 \mathrm{PhD}$ holder but there are currently have only 1700 holders [18]. Another study in developing country Uganda, revealed that most complains come from the students about unqualified lecturers which do not have $\mathrm{PhD}$ and there are no professors teaching them. Hence, unsatisfactory students' will be a major impact factor on the academicians' performance assessment thus later could affect their individual performance [5]. It is important to critically investigate whether the academicians' qualification may influence the performance achievement. Thus, it is hypothesized that $\boldsymbol{H 3}$ : there is a significant relationship between the importance of academic qualifications and BSC adoption in assessing academicians' performance

Figure 2 presents the conceptual framework for this study. The three independent variables are leadership support, importance of academic qualifications and communication channel. Whereas, the dependent variable of this study is the academicians' performance being examine using BSC. The first independent variable is leadership support. this variable is adopted in this study based on a study by [37]. Second variable is importance of academic qualifications, chosen based on a study by [38]. The third variable is communication channel variable which was based on a study conducted by [39].

The proposed framework in this research is as follows:

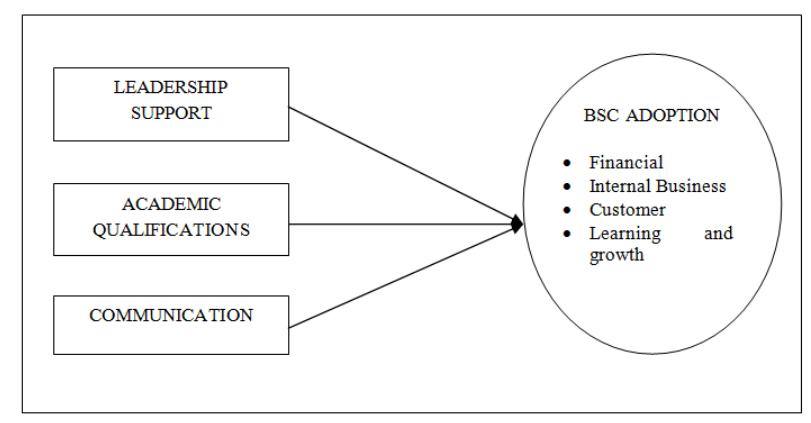

Fig. 2: Conceptual framework

\subsection{Malaysian Institutions of Higher Learning}

Malaysian Institution of Higher Learning (IHL) is under the administration of the Ministry of Education Malaysia (MOE). Table 2 indicates the total of Malaysian IHL. The Private university comprises $85 \%$ of the total IHL in Malaysia. The mission is to develop a higher education environment that will shape the development of academic and IHL [12]. Recently, Malaysian IHL has made a tremendous achievement in terms of the number of graduates generated both in public and private institutions $[31,40]$. With the intense pressure for internationalization of IHL, the Malaysian Federal government has initiated the National Higher Education Action Plan 2015-2025. This aims to reform the higher education quality in Malaysia to become a world class educational hub in Southeast Asia region [31]. This is in line with the aim of the Malaysian government to make Malaysia as the center of the educational hub and to internationalize Malaysian education.

Table 2: Malaysian IHLs

\begin{tabular}{|l|l|l|l|}
\hline No & Types of Institutions & Total & $\%$ \\
\hline 1. & Public University & 20 & 15 \\
\hline 2. & Private University/ University College & 111 & 85 \\
\hline Total & 131 & \\
\hline
\end{tabular}

\section{Methodology}

\subsection{Research Methodology and Design}

This study utilized survey questionnaire for data collection. The survey questionnaire was used to gather the perception of academician towards BSC as their PMS tools. The questionnaire is constructed into five sections namely; Section A (Demographic Information), Section B (Academic Performance), Section C (Leadership), Section D (Academic Qualification) and Section E (BSC adoption). Seven-point Likert scale was used for the respondents to indicate their level of agreement. The respondents consist of 200. From the 200 questionnaires distributed, 165 were returned. Out of the 165 returned questionnaires, 150 were usable while only 15 were excluded due to incomplete response. The final sample consists of 150 respondents which contributed to an overall usable response rate of $91 \%$. Some expert considered $25 \%$ to $36 \%$ response rate to be acceptable [5]. The Statistical Package for Social Science (SPSS) version 21 was used to provide the descriptive analysis of the respondents who have participated in the survey. 


\section{Finding}

\subsection{Respondents' Background}

Table 3 of respondents' background covers in the terms of their gender, age, academic qualifications, job title, working experience and years of service. Overall, under respondents' demographic information, the results illustrated that there are about almost equal distribution of female and male academicians in the university. As can be seen in Table $332 \%$ respondent's age is between 25 to 35 years old. The results also showed that a majority of academician qualification in the university have Masters', followed by Doctoral and Bachelors' qualification. This finding indicates that qualification is one of the most important criteria in becoming an academician. With regards to the job title, it was revealed that a majority of respondents hold the Lecturer position instead of Senior Lecturer, Dean, Associate Professor and Professor. Furthermore, the results demonstrated that most a majority of the respondents' working experience is within one to five years in the education sector. This revealed that most of the respondents are relatively new in the education sector and perhaps it is also possible for them to acquire previous working experiences in other areas. The final section of demographic information is 'years of service'. The results showed that the majority of the respondents are still new in the university with one to five years of service. This might be explained that whether the respondents just started their career or perhaps the turnover of employee is high in private university.

Table 3: Respondents' Background

\begin{tabular}{|c|c|c|}
\hline & Frequency & Percentage \\
\hline \multicolumn{3}{|l|}{ Gender } \\
\hline Male & 70 & $41.8 \%$ \\
\hline Female & 75 & $58.2 \%$ \\
\hline \multicolumn{3}{|l|}{ Age } \\
\hline Less than 25 years & 7 & $4.7 \%$ \\
\hline $25-35$ years & 48 & $32 \%$ \\
\hline $36-45$ years & 35 & $23 \%$ \\
\hline $46-55$ years & 31 & $21 \%$ \\
\hline More than 55 years & 29 & $19 \%$ \\
\hline \multicolumn{3}{|c|}{ Academic Qualifications } \\
\hline Bachelor's & 6 & $4 \%$ \\
\hline Master's & 97 & $65 \%$ \\
\hline Doctoral & 47 & $31 \%$ \\
\hline \multicolumn{3}{|l|}{ Job Tittle } \\
\hline Lecturer & 63 & $42 \%$ \\
\hline Senior Lecturer & 37 & $25 \%$ \\
\hline Dean & 29 & $19 \%$ \\
\hline Associate Professor & 13 & $8.7 \%$ \\
\hline Professor & 8 & $5 \%$ \\
\hline \multicolumn{3}{|c|}{ Working experience as an academician } \\
\hline $1-5$ years & 51 & $34 \%$ \\
\hline $6-10$ years & 38 & $25 \%$ \\
\hline $11-15$ years & 30 & $20 \%$ \\
\hline $16-20$ years & 14 & $10 \%$ \\
\hline More than 20 years & 17 & $11 \%$ \\
\hline
\end{tabular}

\subsection{Leadership}

This section aims to indicate their level of agreement on the importance of leadership support for the performance of BSC adoption in assessing academicians' performance. The scale used for this measurement ranged from 1 (strongly disagree) indicated that the academicians' does not agree with the leadership support factor in enhancing their individual performance to 7 (strongly agree) which indicated that the academicians' extensively agree with the leadership support factor in enhancing their individual performance. The overall mean score for this variable is 4.28 . The highest mean score is $4.67(\mathrm{SD}=1.69)$ it seemed that "my leader in my department always recognizes staff's achievement with encouragement and support" suggesting that recognitions and rewards might influence the academicians' performance. While, the lowest mean score is
$3.82(\mathrm{SD}=1.66)$ indicates that respondents disagree with " $m y$ leader in my department seldom gives supports in activities involving the performance activities" (e.g. send to training, involvement in student activities). This result indicates that supports from leader were important in faculty activities in assessing academicians' performance.

\subsection{Academic Qualifications}

The overall mean score for this variable is 5.82 . The highest mean score is $6.00(\mathrm{SD}=0.79)$ and this shows that the academicians agree with the statement 'I am aware that my academic qualification can help the faculty to achieve the target performance'. Whereas, the lowest mean score is $5.73(\mathrm{SD}=1.16)$ suggesting that respondents disagree with 'I am aware that different level of qualification will have different types of performance assessments'. This indicates that most respondents agree that academic qualifications play important roles in enhancing academicians' performance and the university. They too agree that a different performance measurement should be developed for the different level of qualification. This result supports the findings from [24] study, where they proved that qualification is one of the crucial factors in determining the success of universities' performance besides other factors such as opportunities, review of curriculum and communications channel. Furthermore, findings from a study by [41] revealed that the education sector had failed to meet the international standard which is one of top 300 ranking universities due to the lack of qualified and knowledgeable academicians.

\subsection{Communication}

The five items related to communication channel which ranged from 1 (strongly disagree) to 7 (strongly agree), within this construct, the lowest scoring item is the item R2 "Effective communication between top management and an academicians' signal that the organization does not care about their employees". The mean is 3.91 (std. dev=1.65). The item with the highest score is R5 "Effective communication avoid any potential of miscommunication that could arise in the future time" with the mean is 4.96 (std. dev=1.23). This indicates that academicians agree that communication channel plays important role in the performance measurement process. Schobel [42] claimed that one of the major interests of all organizations is to increase the performance of their employees through communication flow.

\subsection{BSC Measurement System}

The result indicates that most respondents extensively agree to a certain extent on BSC adoption in assessing the academicians' performance. This finding in line with the objective of this study is to examine the extent of BSC adoption and investigate the factors that associated with the BSC adoption in assessing academicians' performances in a private IHL. The highest mean score is $5.64(\mathrm{SD}=$ $1.35)$ whereas the lowest mean score is $3.51(\mathrm{SD}=1.56)$. Based on the results, "Meeting the dateline for teaching files, final exam papers and marks entry" activity was ranked the highest as a measurement for their performance assessment. This result explained that the outcome of the teaching processes is considered as very important to be used as a performance measurement. Meanwhile, the lowest mean result showed that respondents disagree that "Decrease the number of professionals' membership" would enhance their performance measurement since, professionals' membership and industrial certification is very crucial in the education sector. Leadership has a moderate relation with Balance Scorecard.

\subsection{Correlation Analysis}

The correlation indicates a significant relationship ( $\mathrm{r}=.461$, $\mathrm{p}<0.000$ ), which shows that a change in leadership would affect significant change in the balance scorecard. Communication has a 
moderately strong relation with Balance Scorecard. The correlation indicates a significant relationship $(r=.606, p<0.000)$, which shows that a change in communication would affect significant change in the balance scorecard. Academic Quality has a moderate relation with Balance Scorecard. The correlation indicates a significant relationship ( $r=.436, \mathrm{p}<0.000$ ), which shows that a change in academic quality would affect significant change in the balance scorecard.

\subsection{Multiple Regression Analysis}

Based on the results of the hypotheses in table 4, it can be concluded that in overall, there are insignificant relationships between leadership support and communication channel and BSC adoption in assessing academicians' performance in Malaysian private institution of higher learning, but there is a significant positive relationship between importance of academic qualifications and BSC adoption in assessing academicians' performance Malaysian private institution of higher learning. The finding from hypothesis one, to investigate a relationship between leadership support and BSC adoption in assessing academicians' performance is inconsistent with the findings from the study conducted by [43] in which the authors found the positive impacts of performance measurement and leadership support and a study by [14] investigated the achievement of the redesign of BSC to fit the organization culture and they found leadership support was influential to the success of BSC implementation [13], a failure of leadership support in any organizations might due to lack of leadership focus to better manage change or execute strategy. This view is supported by [44]. The author reported that to ensure the success of leadership support process in terms of emotion and financially should involve from the beginning of the leadership process.

Table 4: Multiple Regressions

\begin{tabular}{|c|c|c|c|c|c|}
\hline \multirow[t]{2}{*}{ Model } & \multicolumn{2}{|c|}{$\begin{array}{l}\text { Unstandardized Co- } \\
\text { efficients }\end{array}$} & \multirow{2}{*}{$\begin{array}{l}\begin{array}{l}\text { Standardized Co- } \\
\text { efficients }\end{array} \\
\text { Beta } \\
\end{array}$} & \multirow[t]{2}{*}{$\mathbf{t}$} & \multirow[t]{2}{*}{$\begin{array}{l}\text { Si } \\
\text { g. }\end{array}$} \\
\hline & B & $\begin{array}{l}\text { Std. Er- } \\
\text { ror }\end{array}$ & & & \\
\hline $\begin{array}{l}\text { (Con- } \\
\text { stant) }\end{array}$ & 1.350 & .374 & & $\begin{array}{l}3.6 \\
07\end{array}$ & $\begin{array}{l}.00 \\
0\end{array}$ \\
\hline $\begin{array}{l}\text { Lead- } \\
\text { ership }\end{array}$ & .188 & .055 & .267 & $\begin{array}{l}3.4 \\
39 \\
\end{array}$ & $\begin{array}{l}.00 \\
1 \\
\end{array}$ \\
\hline $\begin{array}{l}\text { Com- } \\
\text { muni- } \\
\text { cation }\end{array}$ & .253 & .063 & .337 & $\begin{array}{l}4.0 \\
28\end{array}$ & $\begin{array}{l}.00 \\
0\end{array}$ \\
\hline $\begin{array}{l}\text { Aca- } \\
\text { demic } \\
\text { Quali- } \\
\text { fication }\end{array}$ & .287 & .063 & .312 & $\begin{array}{l}4.5 \\
62\end{array}$ & $\begin{array}{l}.00 \\
0\end{array}$ \\
\hline
\end{tabular}

The second hypothesis was to test the relationship between the importance of academic qualifications and BSC adoption in assessing academicians' performance and the finding revealed a significant positive relationship between both variables. The reason might be that according to the current BSC adoption in certain Malaysian private institutions of higher learning performance indicators used in assessing academicians' performance are categorized based on the level of qualification of academicians. This indicates that importance of academic qualifications is crucial in determining the successful of BSC adoption in assessing academicians' performance according to their level of education [5]. This result was also supported by [7] and he claimed that different academic qualifications should be measured with different performance indicators as it will provide accurate results based on different level of capability The third hypothesis, test the relationship between communication channel and BSC adoption to assess academicians' performance at a Malaysian private institution of higher learning however, the hypothesis was to be rejected. This result indicates that communication channel in organizations is unlikely will affect BSC adoption in assessing academicians' performance. This finding is inconsistent with the study by $[22,45]$ they claimed that one of the major interest of all organizations is to increase the performance of their employees through communication flow.

Meanwhile, in order to measure the level of agreement using the BSC in assessing academicians' performance, it was found that to a great extent of Malaysian private IHLs had adopted the BSC as a performance measurement tool. This can be further supported based on the results from the descriptive analysis of the BSC adoption, which revealed that most respondents extensively agree with the measurement used in assessing academicians' performance. The result supported from a few studies conducted by $[7,33,46]$ and where they revealed that BSC adoption is suitable to assess academic performances at the individual level. The results indicate the awareness of respondents on BSC adoption in assessing their individual performance.

\section{Conclusion}

This study aims to examine the extent of BSC adoption and investigate the factors that associated to the BSC in assessing academicians' performances in a private Malaysia's IHL. Therefore, this study aims to examine the extent of BSC adoption and investigate the factors that associated with the BSC adoption. The concept of BSC has been widely adopted in the business sector, but the education sector apparently has not embraced the BSC concept widely [1].

Therefore, this study was conducted to examine the adoption of BSC in assessing academician' performance in selected Malaysian's private IHL. The introduction of the BCS in the education sector revealed that financial and non-financial perspectives will increase the effectiveness of employees' performance, hence further increasing the reputation and economic condition of the IHL [19]. With regards to identifying factors that influence the adoption of BSC in assessing academicians' performance, three hypotheses were constructed based on the literature review. This study hypothesized that leadership supports, importance of academic qualifications and communication channel have significant relationship on BSC adoption in assessing academicians' performance.

\section{Acknowledgement}

We would like to express our sincere gratitude to the Ministry of Higher Education (MOHE) Malaysia for the financial assistance to conduct this research. A special thank goes to UNISEL, IUKL and UiTM Malaysia for the consideration for us to carry out this research. This research was supported under the Fundamental Research Grant Scheme (FRGS).

\section{References}

[1] Arokiasamy ARA, "An Analysis of Globalization and Higher Education in Malaysia", Australian Journal of Business and Mnagement Research, Vol.1, No.9, (2011), pp.73-81.

[2] Chenhall RH, "Integrative strategic performance measurement systems, strategic alignment of manufacturing, learning and strategic outcomes: an exploratory study", Accounting, Organizations and Society, Vol.30, No.5, (2005), pp.395-422.

[3] Kaplan RS \& Norton DP, The Balanced Scorecard-Measures that Drive Performance The Balanced Scorecard - Measures, Harvard Business Review, (1992).

[4] Kaplan RS \& Norton DP, Applying the Balanced Scorecard, (2001a)

[5] Kaplan RS \& Norton DP, "Transforming the Balanced Scorecard from Performance Measurement to Strategic Management : Part II", American Acoounting Association, Vol.15, No.2, pp.147-160.

[6] Zain NM, Sulaiman, S \& Ramli A, "Balanced Scorecard Implementation within a Malaysian Government-Linked Company", Accounting Research Institute and Faculty of Accountancy, Vol.7, No.1, (2012), pp.29-58

[7] Gumport PJ, "Academic restructuring: Organizational change and institutional imperatives", The International Journal of Higher Education Research, Vol.39, No.1, (2000), pp.67-91 
[8] Al-Turki, U \& Duffuaa S, "Performance measures for academic departments", International Journal of Educational Management Vol.17, No.7, (2003), pp.330-338.

[9] Aljardali H., Kaderi M \& Levy-Tadjine T, "The Implementation of the Balanced Scorecard in Lebanese Public Higher Education Institutions", Procedia - Social and Behavioral Sciences, Vol.62, (2012a), pp.98-108.

[10] Azmi A, Mehra S \& Pletcher M, "THE DECLINING NEED FOR TRADITIONAL PERFORMANCE”, Journal of Business Administration Online, Vol.1, No.2, (2002), pp.1-14.

[11] Munir R, Baird K, Perera S, "Performance measurement system change in an emerging economy bank", Accounting, Auditing \& Ac countability Journal, Vol.26, No.2, (2013), pp. 196-233.

[12] Chan APC \& Chan APL, "Key performance indicators for measuring construction success", Benchmarking: An International Journal, Vol.11, No.2, (2004), pp.203-216.

[13] Zhijun LIN, ZengbiaoYU \& Zhang L, "Performance outcomes of balanced scorecard application in hospital administration in China", China Economic Review, Vol.30, (2014), pp1-15.

[14] Blueprint Report, (2012), Malaysia Education Blueprint 20132025.

[15] Chen SH, Wang HH \& Yang KJ, "Establishment and application of performance measure indicators for universities", The TQM Journal, Vol.21, No.3, (2009), pp.220-235.

[16] Yee CP \& Mokhtar AHA, “International Students' Learning Experiences At Private Higher Education Institutions In Malaysia", Proceeding of the Global Summit on Education, (2013), pp.11-12.

[17] Bunoti S, "The Quality of Higher Education in Developing Countries Needs Professional Support", 22nd International Conference on Higher Education, (2009), pp.1-10.

[18] Umashankar V \& Dutta K, "Balanced scorecards in managing higher education institutions: an Indian perspective", International Journal of Educational Management, Vol.21, No.1, (2007), pp.54-67.

[19] Al-Turki U \& Duffuaa S, "Performance measures for academic departments", International Journal of Educational Management, Vol.17, No.7, (2003), pp.330-338.

[20] Nejati M, Farid D \& Mirfakhredini M, "PRIORITIZING HIGHER EDUCATION BALANCED SCORECARD PERFORMANCE INDICATORS USING FUZZY", Lex ET Scientia International Journal, Vol.15, No.2, (2008), pp. 338-349.

[21] Bhagwat R \& Sharma MK, "Performance measurement of supply chain management: A balanced scorecard approach", Computers \& Industrial Engineering, Vol.53, No.1, (2007), pp.43-62.

[22] Jusoh R, Ibrahim DN \& Zainuddin Y, "The performance consequence of multiple performance measures usage: Evidence from the Malaysian manufacturers", International Journal of Productivity and Performance Management, Vol.57, No.2, (2008), pp.119-136.

[23] Hassan H, Amir AM \& Maelah R, "Peranan Pengukuran Prestasi Strategik ke Atas Kepuasan Kerja dan Kekuasaan Psikologi dalam Kalangan Pengurus dalam Sektor Automotif”, Jurnal Pengurusan, Vol.34, (2012), pp.65-78.

[24] Franceschini F \& Turina E, "Quality improvement and redesign of performance measurement systems: an application to the academic field", Quality \& Quantity, Vol.47, No.1, (2011), pp.465-483.

[25] Micheli P \& Manzoni J-F, "Strategic Performance Measurement: Benefits, Limitations and Paradoxes", Long Range Planning, Vol.43, No.4, pp.465-476.

[26] Yüksel H \& Coşkun A, "Strategy Focused Schools: An Implementation of the Balanced Scorecard in Provision of Educational Services", Procedia - Social and Behavioral Sciences, Vol.106, (2013), pp.2450-2459.

[27] Karathanos D \& Karathanos P, "Applying the Balanced Scorecard", Journal of Education for Business, (2005).

[28] Lawrence S \& Sharma U, "Commodification of Education and Academic LABOUR - Using the Balanced Scorecard in a University Setting", Critical Perspectives on Accounting, Vol.13, No.5-6, (2002), pp.661-677.

[29] Khan MK \& Mahmood S, "Strength for Today and Bright Hope for Tomorrow", 10(July), (2010), pp.235-245.

[30] Zangoueinezhad A \& Moshabaki A, "Measuring university performance using a knowledge-based balanced scorecard", International Journal of Productivity and Performance Management, Vol.60, No.8, (2011), pp.824-843.

[31] Ukko J, Tenhunen J \& Rantanen H, "Performance measurement impacts on management and leadership: Perspectives of management and employees", International Journal of Production Economics, Vol.110, No.1-2, (2007), pp.39-51.
[32] Rajhans K, "Effective Organizational Communication : a Key to Employee Motivation and Performance", Interscience Management Review (IMR), Vol.2, No.2, (2012), pp.81-85.

[33] McDevitt R, Giapponi C \& Solomon N, "Strategy revitalization in academe: a balanced scorecard approach", International Journal of Educational Management, Vol.22, No.1, (2008), pp.32-47.

[34] MoHE. (2007a). Pelan strategik pengajian tinggi negara melangkau tahun 2020, Putrajaya.

[35] Muniapan B, Issues And Challenges Of Management. eprints.um.edu.my/31/1/balakrishnan.pdf, (2007), pp.1-12.

[36] Narang R \& Dwivedi A, "Managing The Job Satisfaction Of Knowledge Workers: An Empirical Investigation Ritu Narang and Alka Dwivedi", Asia Pacific Journal of Business and Management, Vol.1, No.1, (2010a), pp.1-14.

[37] Neves P \& Eisenberger R, "Management Communication and Employee Performance: The Contribution of Perceived Organizational Support", Human Performance, Vol.25, No.5, (2012), pp.452-464

[38] Papenhausen C \& Einstein W, "Implementing the Balanced Scorecard at a college of business", Measuring Business Excellence, Vol.10, No.3, (2006), pp.15-22.

[39] Pereira MM, "The implementation of the balanced scorecard in a school district: Lessons learned from an action research study", International Journal of Productivity and Performance Management, Vol.61, No.8, (2012), pp.919-939.

[40] Philbin SP, "Design and implementation of the Balanced Scorecard at a university institute", Measuring Business Excellence, Vol.15, No.3, (2011a), pp.34-45.

[41] Rogers EM, Medina UE, Rivera MA \& Wiley CJ, "Complex Adaptive Systems And The Diffusion Of Innovations", The Innovation Journal: The Public SectorInnovation Journal, Vol.10, No.3, (2005), pp.1-26.

[42] Schobel K, "Balanced Scorecards in education: focusing on financial strategies", Measuring Business Excellence, Vol.16, No.3, (2012), pp.17-28.

[43] Smith G, Smith A \& Clarke A, "Evaluating service quality in universities: a service department perspective", Quality Assurance in Education, Vol.15, No.3, (2007), pp.334-351.

[44] Greatbanks R \& Tapp D, "The impact of balanced scorecards in a public sector environment: Empirical evidence from Dunedin City Council, New Zealand", International Journal of Operations \& Production Management, Vol.27, No.8, (2007), pp.846-873.

[45] Tapinos E, Dyson RG \& Meadows M, "The impact of performance measurement in strategic planning", International Journal of Productivity and Performance Management, Vol.54, No.5/6, (2005), pp.370-384.

[46] Tung A, Baird K \& Schoch HP, "Factors influencing the effectiveness of performance measurement systems", International Journal of Operations \& Production Management, Vol.31, No.12, (2011), pp.1287-1310. 